\title{
Urate Crystals Stimulate Production of Tumor Necrosis Factor Alpha from Human Blood Monocytes and Synovial Cells

\author{
Cytokine mRNA and Protein Kinetics, and Cellular Distribution
}

Francesco S. di Giovine, Stephen E. Malawista, ${ }^{*}$ Elisabeth Thornton, and Gordon W. Duff

Molecular Immunology Group, University Department of Medicine, Northern General Hospital, Edinburgh, United Kingdom; and

*Section of Rheumatology, Department of Internal Medicine, Yale University School of Medicine, New Haven, Connecticut 06510

\begin{abstract}
Crystals of monosodium urate (MSU) provide a dose-dependent stimulus for the production by human blood monocytes of tumor necrosis factor (TNF), a cytokine with proinflammatory properties; TNF activity was inhibited selectively by monoclonal antibody to TNF alpha. Biologically active cell-associated TNF activity peaked at $3 \mathrm{~h}$ and was exceeded at $6 \mathrm{~h}$ by extracellular activity, which peaked at 12-18 h. Comparable kinetics were observed with immunoreactive TNF alpha. TNF alpha mRNA accumulation in monocytes stimulated with MSU crys' tals appeared as a single peak at 2-4 h, kinetics compatible with rapid production of a short half-life transcript. In contrast, crystals of calcium pyrophosphate or of hydroxyapatite did not stimulate significant production of TNF or of message.

Fresh tophaceous material from a patient with gout contained significant levels of TNF alpha and cells cultured from the tophus produced TNF alpha in vitro. In rheumatoid synovial cells, spontaneous release of TNF alpha was increased by in vitro exposure to MSU crystals.

Taken together with earlier work, these results support an expanded view of gouty inflammation in which the crystalstimulated production of cytokines provides a crucial link between crystal deposition and many of the clinical and pathological facts of both acute and chronic gouty arthritis. (J. Clin. Invest. 1991. 87:1375-1381.) Key words: gout • inflammation • tumor necrosis factor $\bullet$ arthritis $\bullet$ gene expression
\end{abstract}

\section{Introduction}

Acute gouty arthritis is thought to be an inflammatory response to microcrystals of monosodium urate (MSU) ${ }^{1}$ that precipitate in joint tissues from supersaturated body fluids or are shed from preexisting articular deposits (for review, see 1). Until the last decade, urate crystals were thought to interact primarily with PMN, the cells within which they are found in

Dr. di Giovine's and Dr. Duff's present address is: Section of Molecular Medicine, University Department of Medicine, Royal Hallamshire Hospital, Sheffield S10 2JF, UK, where reprint requests should be addressed to Dr. di Giovine.

Received for publication 3 October 1990 and in revised form 3 December 1990

1. Abbreviations used in this paper: CPPD, calcium pyrophosphate dihydrate; EP, endogenous pyrogen; HA, hydroxyapatite; hr, human recombinant; MSU, monosodium urate; TNF, tumor necrosis factor.

J. Clin. Invest.

(c) The American Society for Clinical Investigation, Inc. 0021-9738/91/04/1375/07 \$2.00

Volume 87, April 1991, 1375-1381 acute gouty synovial fluid. A proposed sequence consisted of the ingestion of crystals by PMN, generation of PMN-derived inflammatory mediators including chemotactic factors, and infiltration of more PMN, producing a vicious cycle of propagation and amplification of the inflammatory response. Urate crystals themselves were shown in vitro to stimulate a number of inflammatory mediators (2).

Useful as far as it went, this scheme could account neither for the initiation of gouty inflammation, free crystals also being present in tissues between inflammatory attacks, nor for associated systemic features (fever, leukocytosis, generation of acute-phase reactants), which appeared, as of the early $1980 \mathrm{~s}$ $(3,4)$, no longer attributable to PMN. These considerations led us initially to examine the release of "endogenous pyrogen" (EP; the original designation for fever-producing cytokines) from monocytes and macrophages exposed to $\operatorname{MSU}(5,6)$. We found that the activation process for EP production was dose dependent, did not require phagocytosis of the crystals, was independent of serum factors or of mediation by other blood leukocytes, and could not be attributed to contamination of the crystal by bacterial endotoxin (LPS) (5). We then examined in detail IL-1 (7), a pyrogenic cytokine with multiple biological actions, finding high levels of $1 \mathrm{~L} 1$ beta released.

Tumor necrosis factor (TNF)/cachectin, the subject of this report, is a $17-\mathrm{kD}$ inducible peptide (8) produced mainly by activated macrophages, with biological actions very similar to those of IL-1 (9), although it is the product of a different gene (10) and acts via a distinct set of cell surface receptors $(11,12)$. Systemic properties of TNF include induction of fever (13), acute phase response (14), and metabolic (15) and hemodynamic changes $(16,17)$. Of relevance to the pathogenesis of inflammatory arthritis and joint destruction, TNF alpha stimulates cartilage (18) and bone (19) resorption, activates synovial cells to produce proinflammatory mediators (20), and increases expression of MHC (21) and adhesion (22) molecules. It also induces the production of other macrophage-derived cytokines, such as IL-1 (13), IL-6 (23), and IL-8 (24). TNF alpha has been found in symptomatic joints of arthritic patients and has been implicated in acute and chronic arthritic diseases (25-27).

Taken together with earlier studies, the results of this work support an expanded view of gouty inflammation (6) that can account for many clinical and pathological facts of gout that were unapproachable a decade ago.

\section{Methods}

Materials. All reagents and culture media had undetectable levels of endotoxin as assessed by Limulus lysate gelation (E-Toxate; Sigma Chemical Co., St. Louis, MO; lower detection limit: $0.025 \mathrm{IU} / \mathrm{ml}$ ). Human peripheral blood cells were cultured in RPMI 1640 medium 
(Gibco Ltd., Paisley, UK), while L929 cell culture and cytotoxicity assays were performed in MEM medium (Sigma). Both media were supplemented with $2 \mathrm{mM}$ glutamine and $5 \%$ heat-inactivated FCS (Gibco) unless otherwise stated.

Human recombinant (hr) TNF alpha and MAb to TNF alpha ("TNF-E") were kindly given by Dr. G. Adolf, Boehringer Institute, Wien, Austria. The specific neutralizing activity in the cytotoxicity assay was $\sim 300 \mathrm{ng} \mathrm{hrTNF}$ alpha/mg antibody (data not shown).

Cell culture. Blood from young healthy volunteers was collected in preservative-free heparin (Leo Laboratories Ltd., Aylesbury, UK) and immediately processed. Mononuclear cells were separated by gradient fractionation on Ficoll-Hypaque (pyrogen tested-Lymphoprep; Nyegaard Co., Oslo, Norway), and selected by adherence to plastic multiwell dishes (Nunc, Roskilde, Denmark). Medium was added to a final cell concentration of $10^{6} / \mathrm{ml}$. Cells $(60-80 \%$ monocytes by morphological criteria) were cultured for different times in the presence or absence of test stimuli and the centrifuged supernatants were aliquoted and stored (representing extracellular fractions). The cells were subjected to three cycles of rapid freeze-thawing in fresh medium (at initial volume) to obtain the cell-associated fraction. Extracellular and cell-associated fractions were stored in aliquots at $-70^{\circ} \mathrm{C}$ until tested.

Cultures for mRNA analysis were similarly prepared, and cells were removed by gentle scraping of the wells with a rubber policeman (Costar, Data Packaging Corp., Cambridge, MA) in ice-cold PBS. The cell suspension was washed twice in PBS and immediately processed.

Stimuli. Crystals of MSU, hydroxyapatite (HA), and calcium pyrophosphate dihydrate (CPPD) were prepared as previously described (6). Crystal preparations were resuspended at $10 \mathrm{mg} / \mathrm{ml}$ in PBS, and tested by the Limulus gelation test for bacterial endotoxin (28). We have shown previously (7) that MSU crystals at concentrations used here have no inhibitory effect on endotoxin-induced Limulus gelation (tested down to $0.25 \mathrm{IU}$ LPS-endotoxin/ml). When $10 \mathrm{mg} / \mathrm{ml} \mathrm{MSU}$ crystals in PBS were shaken overnight, the PBS supernatant also was negative in the Limulus test, indicating $<0.0025$ IU soluble endotoxin/mg MSU. Crystal batches with $<0.025$ endotoxin IU/10 mg crystals were aliquoted and stored at $-20^{\circ} \mathrm{C}$ until used. All crystal types were of comparable size (MSU, 8-40 $\mu \mathrm{m}$; CPPD, 15-50 $\mu \mathrm{m}$; HA aggregates, 3-15 $\mu \mathrm{m})$ under incident light microscopy.

LPS (TCA extracted, E. coli 0127:B8 strain, Sigma) was dissolved in PBS and stored at $-20^{\circ} \mathrm{C}$.

TNF assays. For the standard TNF cytotoxicity assay (29), we used L929 cells (a mouse fibrosarcoma line) grown in nonconfluent status in MEM medium, 5\% FCS. As previously described (25), in standard conditions a half-maximal unit is obtained by $25-50 \mathrm{pg} / \mathrm{ml} \mathrm{hrTNF}$ (alpha or beta) and the assay is specific for these cytokines.

TNF alpha was also measured by radioimmunoassay with limits of detection 0.05-5 ng/ml hrTNF alpha (Medgenix, Brussels, Belgium).

$m R N A$ analysis. Human TNF alpha cDNA (1606 bp, Pstl insert in pAT 153) was kindly donated by Dr. W. Fiers (University of Ghent, Belgium). We used the 1180-bp Pstl fragment, which contains the complete coding region (699 bp) for the human TNF alpha precursor (30).

To standardize mRNA extraction and loading, we used a 708-bp PstI-Dral fragment from a p7B6 insert in pBr322 (from Dr. M. Feldmann, Sunley Research Centre, London), which codes for a cell cycleindependent species of mRNA (31).

All fragments were ${ }^{32} \mathrm{P}$-labeled by random oligo priming (32). After separation on Sephadex G50 (Pharmacia LKB Biotechnology, Uppsala, Sweden), cDNA probes were obtained at a sp act of $6-10 \times 10^{8}$ $\mathrm{dpm} / \mu \mathrm{g}$ DNA.

In kinetic studies, total cytoplasmic RNA was prepared (33) from adherent mononuclear cells cultured for different times. At the end of incubation, cells were resuspended in ice-cold $10 \mathrm{mM}$ Tris, $1 \mathrm{mM}$ EDTA ( $\mathrm{pH} 7.0$ ), lysed by detergent, and nuclei were pelleted by centrifugation. Cytoplasmic preparations were extracted with phenol/chloroform and resuspended in $0.9 \mathrm{M} \mathrm{NaCl} / 90 \mathrm{mM}$ sodium citrate/7.4\% formaldehyde for $15 \mathrm{~min}$ at $60^{\circ} \mathrm{C}$. Cytoplasmic preparations were transferred onto nylon membranes (Hybond N; Amersham International, Amersham, UK) using a slot blot apparatus (Minifold II;
Schleicher \& Schuell, Dassel, FRG). Membranes were exposed to UV and prehybridized for $8-20 \mathrm{~h}$ ( $50 \%$ formamide, $240 \mathrm{mM} \mathrm{NaCl}, 30 \mathrm{mM}$ sodium citrate, $40 \mathrm{mM}$ sodium phosphate, $0.02 \%$ Ficoll, $0.02 \%$ polyvinyl pyrrolidone, $0.02 \%$ BSA). Hybridization was carried out in fresh prehybridization solution to which denatured sheared calf thymus and ${ }^{32} \mathrm{P}$-labeled probe had been added. After $18-24 \mathrm{~h}$ at $37^{\circ} \mathrm{C}$, membranes were washed four times $(15 \mathrm{~min})$ in $0.1 \%$ SDS and decreasing salt concentration (from $0.3 \mathrm{M} \mathrm{NaCl}, 30 \mathrm{mM}$ sodium citrate, to $15 \mathrm{mM}$ $\mathrm{NaCl}, 1.5 \mathrm{mM}$ sodium citrate). Blots were visualized by exposure of $\mathrm{x}$-ray films (Agfa-Gevaert, Dunstable, UK) at $-80^{\circ} \mathrm{C}$ with intensifying screens for $4 \mathrm{~h}-4 \mathrm{~d}$. To obtain quantitative data, we scanned autoradiographs at $\mathrm{OD}_{5 s 0}$ in a densitometer (CS9000; Shimadzu Instruments, Kyoto, Japan) (calibration at $\times 16$, integral of peak area $=$ scanning densitometry [SD] units).

For Northern analysis, total cellular RNA was isolated using the guanidinium/phenol method (34). Briefly, cellular proteins were disintegrated in $4 \mathrm{M}$ guanidine isothyocyanate, followed by an extraction with phenol, and equilibration in ice-cold Tris/acetate buffer, pH7.4. After two cycles of chloroform/isoamyl-alcohol (24:1) extractions, total RNA in the final aqueous phase was precipitated in 50\% isopropanol at $4^{\circ} \mathrm{C}$. The pellets obtained were washed in $70 \%$ ethanol and resuspended in $10 \mathrm{mM}$ 3-[N-morpholino]-2-hydroxypropanesulfonic acid (MOPS) buffer.

Samples were size-fractionated in agarose/formaldehyde gels $(1.2 \%$ Seakem agarose, $6.7 \%$ formaldehyde, $20 \mathrm{mM}$ MOPS, $5 \mathrm{mM}$ sodium acetate, $1 \mathrm{mM}$ EDTA), and transferred overnight to nylon membranes by capillary blotting. All subsequent steps were as previously indicated for total cytoplasmic RNA preparations.

$T N F$ in tophus. Fresh tophaceous material was obtained by needle aspiration from an interphalangeal joint. The mass was immediately fragmented and resuspended in $0.5 \mathrm{ml}$ serum-free RPMI 1640 medium, and then pelleted by centrifugation. Supernatant was aspirated and tested for immunoreactive TNF alpha. The pellet was resuspended in fresh medium and fractionated on a Ficoll density gradient. Cells (80\% polymorphonuclear, $15 \%$ lymphocytes, $5 \%$ monocytes by morphological criteria) were cultured for $18 \mathrm{~h}$ in RPMI $1640\left(10^{7}\right.$ cells $\left./ \mathrm{ml}\right)$ and supernatants tested for TNF alpha.

\section{Results}

Induction of TNF biological activity by crystals. Human blood adherent mononuclear cells were incubated in the presence or absence of MSU, HA, or CPPD crystals for $18 \mathrm{~h}$. Supernatants were collected and tested for TNF biological activity (Fig. 1). MSU-stimulated cells and, to a lesser extent, cells treated with HA crystals released significant amounts of TNF-like activity. Stimulation by HA crystals was not a constant observation and appeared to be related to the individual donor. Cells incubated in medium only or with CPPD crystals failed to produce any significant extracellular activity. TNF induction by MSU crystals was dose dependent, and in each single series of experiments maximal stimulation occurred at $1.2 \mathrm{mg} \mathrm{MSU} / \mathrm{ml}$. To test the specificity of these biological activities, we tested supernatants in the presence of anti-human TNF alpha monoclonal antibody (TNF-E, kindly provided by Dr. G. Adolf). Results in Table I show selective inhibition of L929 cytotoxicity, indicating that the cytotoxicity observed was mediated by TNF alpha.

TNF alpha production in synovial cells. Freshly isolated human RA synovial fluid mononuclear cells (MNC) spontaneously released immunoreactive TNF alpha in a 20-h incubation (Fig. $2 \mathrm{~A}$ ). This is likely to reflect activation in vivo rather than inadvertent activation during separation procedures, since autologous blood MNC produced no TNF activity without prior stimulation (data not shown). The synovial cells could be further stimulated to release TNF by incubation with 


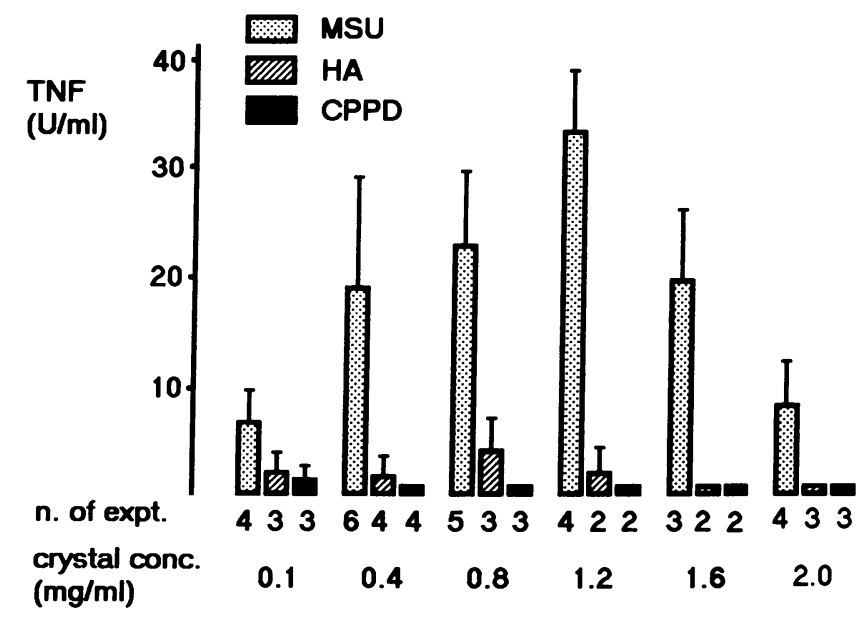

Figure 1. Induction of TNF biological activity by crystals. Human adherent mononuclear cells $\left(10^{6} / \mathrm{ml}\right)$ were incubated for $18 \mathrm{~h}$ in the presence or absence of different doses of MSU, HA, or CPPD crystals. Supernatants were tested for TNF bioactivity in the L929 cytotoxicity assay (in which $1 \mathrm{U}=$ about $40 \mathrm{pg} / \mathrm{ml} \mathrm{hrTNF}$ alpha). Data are expressed as mean $( \pm$ SEM) for the number of experiments indicated. In the same experiments, bioactivity was not detectable in supernatants from cells cultured in the absence of crystals (data not shown).

$0.4 \mathrm{mg} / \mathrm{ml}$ MSU crystals, while HA failed to induce further significant release of TNF alpha.

Kinetics of production and cellular distribution of TNF alpha in MSU crystal-stimulated cells. Cellular fractions representing extracellular and cell-associated compartments were prepared (described in Methods) from crystal-stimulated ad-

Table I. TNF Biological Activity

\begin{tabular}{cccc}
\hline & Sample & $\begin{array}{c}\text { Sample with } \\
\text { MAB anti-TNF } \\
\text { alpha }(1.5 \mu \mathrm{gg} / \mathrm{ml})\end{array}$ & $\begin{array}{c}\text { Sample with } \\
\text { control MAB } \\
(3 \mu \mathrm{g} / \mathrm{ml})\end{array}$ \\
\hline $\begin{array}{c}\text { MSU-induced } \\
\text { supernatant }\end{array}$ & & $U / \mathrm{ml}$ & \\
$\begin{array}{c}0.4 \mathrm{mg} / \mathrm{ml} \\
\text { MSU-induced } \\
\text { supernatant }\end{array}$ & $17.61+0.34$ & $<4$ & $24.16+3.08$ \\
$\begin{array}{c}0.8 \mathrm{mg} / \mathrm{ml} \\
\text { MSU-induced } \\
\text { supernatant }\end{array}$ & $36.92+2.67$ & $<4$ & $42.77+2.98$ \\
$\begin{array}{c}1.2 \mathrm{mg} / \mathrm{ml} \\
\text { LPS-induced } \\
\text { supernatant }\end{array}$ & $27.36+1.08$ & $<4$ & $28.75+2.19$ \\
$\begin{array}{c}100 \mathrm{ng} / \mathrm{ml} \\
\text { hrTNF beta } \\
1 \mathrm{ng} / \mathrm{ml}\end{array}$ & $1469.90+136.97$ & $<4$ & $822.40+123.8$ \\
hrTNF alpha \\
$1 \mathrm{ng} / \mathrm{ml}$
\end{tabular}

L929 cell cytotoxicity by supernatants of stimulated adherent mononuclear cells. Supernatants were tested for TNF biological activity in the presence or absence of specific anti-human TNF alpha monoclonal antibody, or irrelevant mouse anti-human monoclonal (anti-human DR). Results are expressed in half-maximal units per milliliter ( \pm SEM).
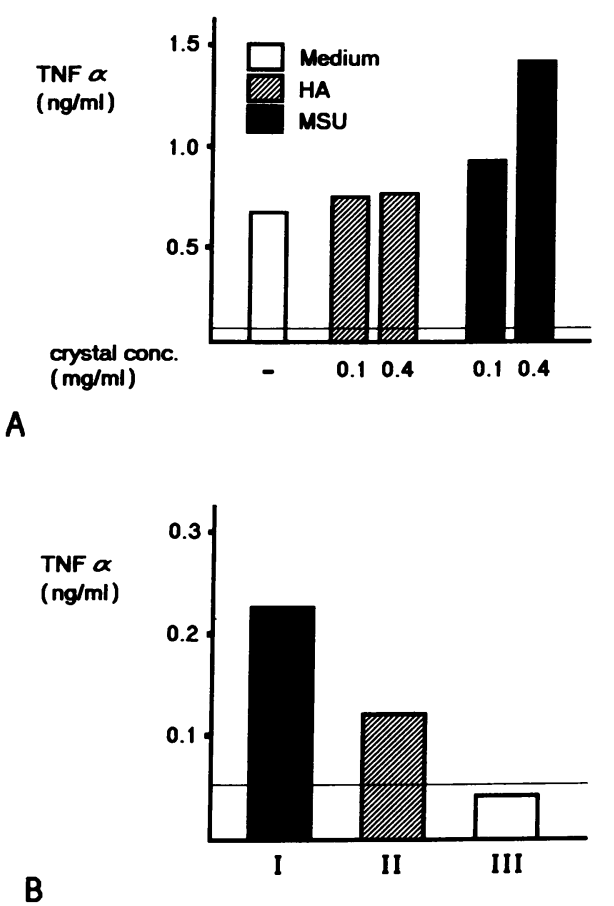

Figure 2. TNF alpha production in synovial cells and in tophaceous material. $(A)$ Synovial fluid mononuclear cells were separated by density centrifugation from freshly aspirated RA exudate fluids, then were allowed to adhere in plastic Petri dishes $(40 \mathrm{~min})$. LPS-free crystals were added to cultures $\left(10^{6}\right.$ cells $\left./ \mathrm{ml}\right)$ at the concentrations indicated, and after $20 \mathrm{~h}$ supernatants were collected and tested in duplicate in a monospecific TNF alpha RIA (lower detection limit, $50 \mathrm{pg} / \mathrm{ml}$ ). (B) TNF alpha in tophus. I, supernatant from freshly aspirated tophus resuspended in $0.5 \mathrm{ml}$ serum-free RPMI 1640. II, supernatant (18-h culture) of cells isolated from gradient centrifugation of tophaceous material. III, supernatant $(18 \mathrm{~h})$ from unstimulated human adherent mononuclear cells. Results are expressed as $\mathrm{TNF}$ alpha $/ 10^{7}$ cells $/ \mathrm{ml}$ and are the mean of two determinations.

herent mononuclear cells. Fractions were collected at different time points $(0-18 \mathrm{~h})$ and tested for TNF activity by bioassay (Fig. $3 \mathrm{~A}$ ). After an initial peak of cell-associated TNF activity at $3 \mathrm{~h}$ after MSU, extracellular TNF at $6 \mathrm{~h}$ exceeded cell-associated TNF, to reach a maximum at 12-18 h. Comparable kinetics were obtained when immunoreactive TNF alpha was measured (Fig. $3 \mathrm{~B}$ ), with $90 \%$ of TNF alpha translocated at $18 \mathrm{~h}$.

In these kinetic experiments, cells stimulated with HA and CPPD did not express TNF biological activity, either cell associated or in the supernatant. Unstimulated cells similarly failed to express TNF activity or immunoreactive TNF alpha, indicating the absence of a preformed TNF alpha protein pool in resting cells.

Crystal-induced TNF alpha mRNA accumulation. Cells incubated for $4 \mathrm{~h}$ in medium or in the presence of HA or CPPD crystals failed to express TNF alpha mRNA (Fig. 4). Cells induced with LPS $(100 \mathrm{ng} / \mathrm{ml})$ or MSU crystals $(0.4 \mathrm{mg} / \mathrm{ml})$ accumulated an mRNA species that migrated in the $1.5-\mathrm{kb}$ region and hybridized with radiolabelled TNF alpha CDNA.

Kinetics of TNF alpha mRNA accumulation were determined by slot blot analysis (Figs. 5 and 6 ). In the same cultures, supernatant TNF alpha was measured by RIA (Fig. 6). Unstimulated cells, but not HA- or CPPD-exposed cells, accumu- 

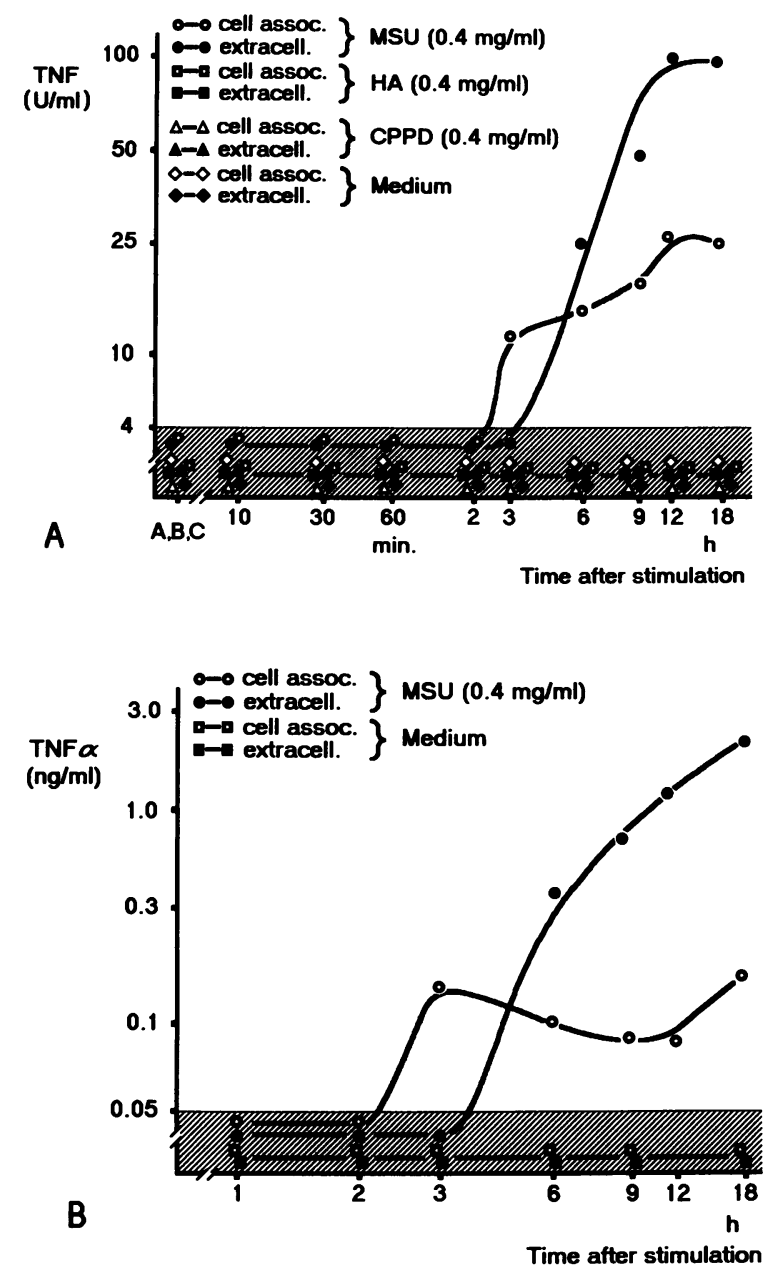

Figure 3. Kinetics of production and cellular distribution of TNF alpha in MSU crystal-stimulated cells. Human adherent mononuclear cells $\left(10^{6} / \mathrm{ml}\right)$ were cultured for up to $18 \mathrm{~h}$ in the presence of MSU, HA, or CPPD crystals. $(A)$ Extracellular and cell-associated fractions were tested for TNF activity, expressed in cytotoxicity units. Each fraction was tested in duplicate rows and eleven dilutions. (B) Immunoreactive TNF alpha was measured by TNF alpha RIA. Results are the mean of duplicate wells (on the horizontal axes: A, cell lysate after density centrifugation; $B$, fractions from cells at the end of plastic adherence; or C, immediately after stimulation [time zero]).

lated detectable levels of TNF alpha mRNA by $6 \mathrm{~h}$ and at 20-30 h. Surprisingly, this was not associated with TNF alpha protein in the supernatants. In contrast, MSU crystals stimulated early accumulation of TNF alpha mRNA, and immunoreactive TNF alpha in the supernatant (Fig. 6).

TNF alpha in tophus. Supernatants of fresh tophaceous material contained $220 \mathrm{pg} / \mathrm{ml}$ TNF alpha (Fig. $2 B$ ), indicating that TNF was present within the gouty tophus in vivo. Cells obtained from the tophus produced $120 \mathrm{pg}$ immunoreactive TNF alpha $/ 10^{7}$ cells after in vitro culture of $18 \mathrm{~h}$ (Fig. $2 \mathrm{~B}$ ).

\section{Discussion}

In this study we found that MSU crystals provide a dose-dependent stimulus for TNF production in human monocytes (Fig. 1). At supraoptimal concentrations of MSU crystals it is likely that reduced TNF alpha production was a consequence of the

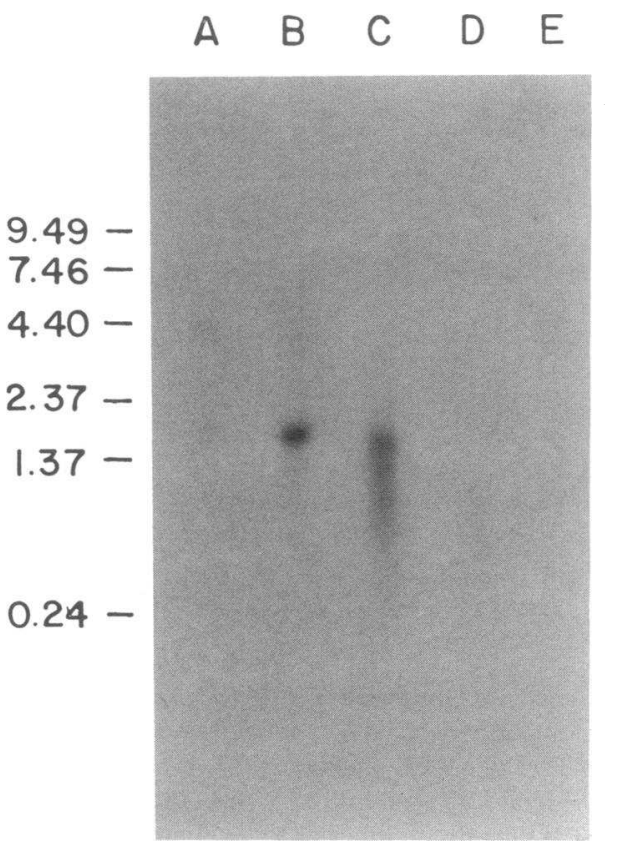

Figure 4. Crystal-induced TNF alpha mRNA accumulation. Total RNA from adherent mononuclear cells $\left(4 \mathrm{~h}, 10^{6} / \mathrm{ml}\right)$ was fractionated in a $1.5 \%$ agarose/formaldehyde gel $(15.0 \mu \mathrm{g} / \mathrm{lane})$ and transferred to membranes. Hybridization to the ${ }^{32} \mathrm{P}$-labelled TNF alpha probe was monitored by autoradiography. Cells had been cultured in control medium (lane $A$ ), or stimulated with LPS, $100 \mathrm{ng} / \mathrm{ml}$ (lane $B$ ), or crystals at $0.4 \mathrm{mg} / \mathrm{ml}$ : MSU (lane $C$ ), HA (lane $D$ ), and CPPD (lane $E)$. Relative positions of RNA size markers, in kilobase, are shown at left.

known cytolytic effects of these crystals. Cytotoxicity was completely inhibited by anti-TNF alpha MAb (Table I), suggesting that TNF beta was not produced in these cultures. HA crystals in some experiments induced release of low levels of TNF bioactivity but this finding was inconsistent and in time-course
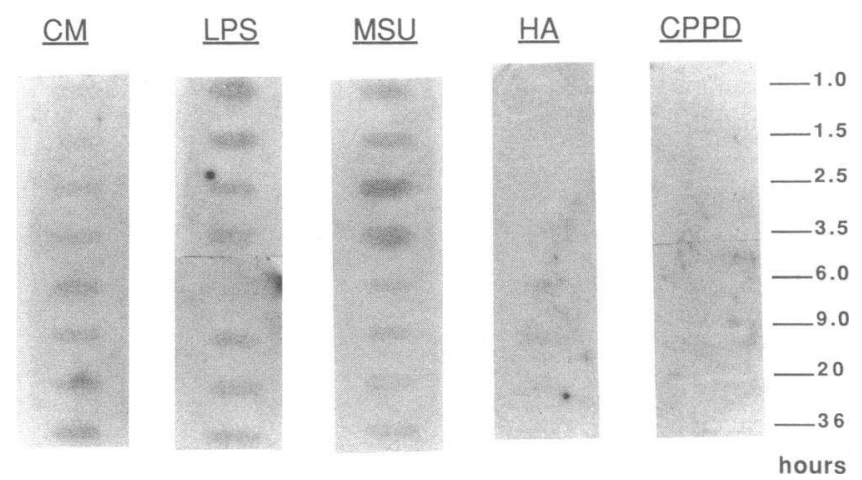

Figure 5. Kinetics of crystal-induced TNF alpha mRNA accumulation. Cytoplasmic RNA preparations were transferred and hybridized to a ${ }^{32} \mathrm{P}$ TNF alpha cDNA probe. Shown are results from preparations of $4 \times 10^{4}$ cells RNA/slot, which had been cultured in the absence of stimulus $(C M)$, or stimulated with lipopolysaccharide ( $L P S$, $100 \mathrm{ng} / \mathrm{ml})$; or crystals at $0.4 \mathrm{mg} / \mathrm{ml}(M S U, H A, C P P D)$. Quantitative data were obtained by scanning at $\mathrm{OD}_{\text {sso }}$ in a Shimadzu CS9000 densitometer, using a $\times 16$ calibration. The area of the peaks was used as a measure of TNF alpha mRNA within each set of cultures (scanning densitometry [SD] units). Hybridization with control probe (p7B6) showed homogeneous loading (data not shown). 

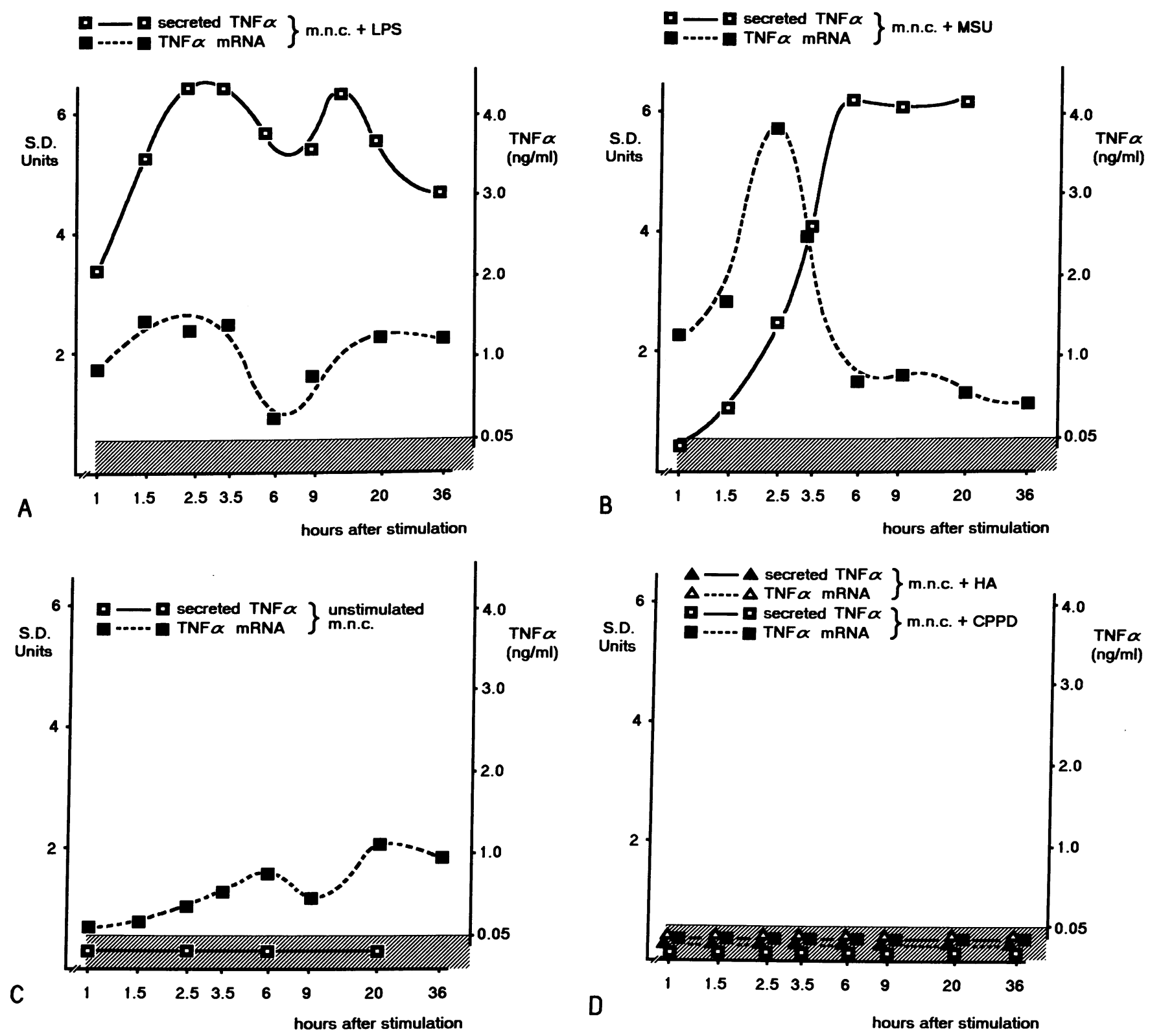

Figure 6. Kinetics of crystal-induced TNF alpha mRNA accumulation and of concomitant extracellular immunoreactive TNF alpha. Levels of TNF alpha mRNA quantified as described in the legend to Fig. 5 are indicated by closed symbols. Open symbols represent levels of extracellular TNF alpha protein assessed by RIA in the same cultures (lower detection limit, $100 \mathrm{pg} / \mathrm{ml}$ ). Adherent cells were cultured for the indicated lengths of time, in the presence of different stimuli: $(A) \mathrm{LPS}, 100 \mathrm{ng} / \mathrm{ml} ;(B) \mathrm{MSU}, 0.4 \mathrm{mg} / \mathrm{ml} ;(C)$ medium control; $(D) \mathrm{HA}$ or CPPD, at $0.4 \mathrm{mg} / \mathrm{ml})$.

experiments (below) was not confirmed. CPPD crystals showed no TNF-inducing activity.

We also found spontaneous production of TNF alpha by RA synovial fluid adherent mononuclear cells (Fig. 2 A). TNF production could be further stimulated by addition of MSU to the cells, while HA crystals had no effect. Ex vivo evidence for the relevance of TNF alpha in gouty arthritis was found in fresh tophaceous material from an interphalangeal joint (Fig. 2 B). It contained significant amounts of immunoreactive TNF alpha, and cells obtained from the tophus continued to release this cytokine over $18 \mathrm{~h}$ incubation ( $120 \mathrm{pg}$ TNF alpha/10 ${ }^{7}$ cells/ml).

The failure of HA and CPPD to induce significant TNF synthesis was confirmed in time-course experiments where neither crystal type induced either cell-associated TNF biological activity (Fig. 3) or mRNA accumulation (Figs. 5 and 6). These two crystals also do not induce significant synthesis of IL-1 in our hands (7).

In contrast, LPS-free crystals of MSU induced time-dependent accumulation of TNF alpha in both cell-associated and extracellular compartments, with detectable levels at $3 \mathrm{~h}$ in cell lysates, followed by extracellular translocation of biologically active TNF alpha, found mainly in the supernatants at 9-18 h (extracellular TNF alpha, $2.24 \mathrm{ng} / \mathrm{ml} ; 90.5 \%$ of the total).

In these cultures, immunoreactive TNF alpha generally followed the pattern of distribution of TNF bioactivity. However, discrepancies were noticed at late stages of incubation, perhaps indicating the presence of cytotoxicity unrelated to TNF alpha and/or production of biological inhibitors (26). It is of interest that we found no evidence of TNF accumulation in the cell-as- 
sociated fractions, suggesting that the reported form of membrane-associated TNF alpha (35) could only exist as a transient event in our conditions.

TNF alpha mRNA accumulation appears as a single peak at 2-4 h (Fig. 6). In studies using phorbol stimulation (36) a similar monophasic response was observed but with maximum levels at a later time $(12-16 \mathrm{~h})$. The mRNA kinetics are compatible with rapid production of a short half-life transcript. Unstimulated cells accumulated low levels of TNF alpha mRNA at late stages of incubation but this was not followed by translocation of immunoreactive protein. This may represent untranslated mRNA as has been reported for TNF alpha in macrophages from $\mathrm{C} 3 \mathrm{H} / \mathrm{HeJ}$ mice (37). The kinetics of production of biologically active TNF alpha are remarkably similar to those of IL-1 alpha and IL-1 beta (38), and would argue against sequential induction of one cytokine by another. The peak level of total TNF produced in response to MSU crystals (2.44 ng/ $\mathrm{ml}$ ) was lower than those of IL-1 in the same experiment (IL-1 alpha, $9.9 \mathrm{ng} / \mathrm{ml}$; IL-1 beta, $10.9 \mathrm{ng} / \mathrm{ml}$ ). The dose-response relation of MSU concentration to total production of TNF alpha, IL-1 alpha, or IL-1 beta was similar in all three cases, with optimal stimulation occurring between 0.8 and $1.2 \mathrm{mg} / \mathrm{ml}$ MSU crystals (38).

TNF and IL-1 have independent proinflammatory and immunopotentiating activities and each could therefore contribute to the response to MSU crystal deposition. Both TNF and IL-1 are powerful stimuli of IL-6 (23) and IL-8 (24) production, which could (respectively) account for the pronounced acute phase response and neutrophil chemotaxis associated with MSU crystal deposition. Both IL-6 and IL- 8 have been found in supernatants after stimulation of monocytes with urate crystals $(39,40)$.

The likely clinical correlates of these considerations, formulated for "EP/IL-1" (6), but expandable to include TNF alpha and the other cytokines that it and IL-1 engender, can be summarized as follows: (a) Initiation of acute gouty arthritis. Urate crystals, brought into contact with mononuclear phagocytes within the joint, can generate cytokines chemotactic for PMN. When the latter cells encounter ingestible particles (urate crystals) they can propagate and amplify the inflammatory response (see Introduction), producing acute gout. As crystals may be present when inflammation is not, they would seem to be the fuel for the inflammatory engine, not the spark; hence acute gout is properly "crystal associated" rather than "crystal induced" (1). Although adsorbed material might affect the phlogistic potential of crystals (2), they still have to be "told" when to change their coats; i.e., there must be a prior series of controls. Candidates for the inflammatory sparks that introduce crystals to resident mononuclear phagocytes would include local trauma, gross or micro-, whose effects in normal individuals (those without crystal "fuel") would quickly fade or remain subclinical. (b) Acute polyarticular gout. Cytokines generated in gouty joints can disseminate to other areas of the body, as evidenced by systemic manifestations such as fever (hypothalamus), leukocytosis (bone marrow), and acute phase reactants (liver). They are therefore prime suspects as the messengers that result in the typical intense inflammation that one sees in overlying skin, and that sometimes lead other joints to become inflamed, as if by "contagion." A logical corollary to the latter point is that the inciting inflammatory cytokines may originate in extraarticular sites of trauma, inflammation, or infection, thus explaining why both acute gouty arthritis and pseudogout are often superimposed upon trauma or infection elsewhere, and why polyarticular gout has a predilection for elderly, debilitated, often febrile individuals. Cytokines arriving in a joint charged with CPPD crystals may be especially important in initiating pseudogout, as those crystals seem not to induce production either of TNF alpha, as shown here, or of IL-1 (7). (c) Tophi and chronic tophaceous gout. Tophi contain IL-1-producing cells (mononuclear phagocytes) in close proximity to IL-1 inducers (urate crystals), surrounded by cytokineinducible material (fibrous tissue). Sometimes tophi reside in characteristic sclerotic-rimmed punched-out areas formerly occupied by material (cartilage and bone) whose resorption is also inducible by cytokines. In chronic tophaceous gout, through persistent stimulation of mononuclear phagocytes, rampant tophaceous material in and about joints may engender chronic inflammatory processes similar to those seen in rheumatoid arthritis, which this condition resembles clinically.

Thus, in view of the biological actions of TNF and IL-1, their reported synergy in several human systems (41-43) and the possibility of mutual induction $(13,44)$, we believe that stimulation of IL-1 and TNF production by MSU crystals may be a crucial link between crystal deposition and both the acute and chronic inflammatory reactions of gouty arthritis.

\section{Acknowledgments}

We thank Dr. Herman Cheung and Dr. Paul Dieppe for their generous provision of microcrystals.

This work was supported by a program grant from the Arthritis and Rheumatism Council for Great Britain, and by the U. S. National Institutes of Health (AR-10493 and AR-07 107).

\section{References}

1. Malawista, S. E. 1977. Gouty inflammation. Arthritis Rheum. 20(Suppl.):S241-248.

2. Terkeltaub, R. A., and M. H. Ginsberg. 1988. The inflammatory reactions to crystals. Rheum. Dis. Clin. North Am. 14:353-364.

3. Hanson, D. F., P. A. Murphy, and B. E. Windle. 1980. Failure of rabbit neutrophils to secrete endogenous pyrogen when stimulated with staphylococci. J. Exp. Med. 151:1360-1371.

4. Dinarello, C. A. 1984. Interleukin 1. Rev. Infect. Dis. 6:51-94.

5. Duff, G. W., E. Atkins, and S. E. Malawista. 1983. The fever of gout: urate crystals activate endogenous pyrogen production from human and rabbit mononuclear phagocytes. Trans. Assoc. Am. Physician. 96:234-245.

6. Malawista, S. E., G. W. Duff, E. Atkins, H. S. Cheung, and D. J. McCarty. 1985. Crystal-induced endogenous pyrogen: a further look at gouty inflammation. Arthritis Rheum. 28:1039-1046.

7. di Giovine, F. S., S. E. Malawista, G. Nuki, and G. W. Duff. 1987. Interleukin 1 (IL 1) as a mediator of crystal arthritis. Stimulation of T cell and synovial fibroblast mitogenesis by urate crystal-induced IL 1. J. Immunol. 138:32133218.

8. Beutler, B., and A. Cerami. 1986. Cachectin and tumour necrosis factor as two sides of the same biological coin. Nature (Lond.). 320:584-588.

9. Dinarello, C. A. 1987. The biology of interleukin 1 and comparison to tumor necrosis factor. Immunol. Lett. 16:227-231.

10. Pennica, D., G. E. Nedwin, J. S. Hayflick, P. H. Seeburg, R. Derynck, M. A. Palladino, W. J. Kohr, B. B. Aggarwal, and D. V. Goeddel. 1984. Human tumour necrosis factor: precursor structure, expression and homology to lymphotoxin. Nature (Lond.). 312:724-729.

11. Smith, C. A., T. Davis, D. Anderson, L. Solam, M. P. Beckmann, R. Jerzy, S. K. Dower, S. D. Cosman, and R. G. Goodwin. 1990. A receptor for tumour necrosis factor defines an unusual family of cellular and viral proteins. Science (Wash. DC). 248:1019-1023.

12. Loetscher, H. R., Y. E. Pan, H. W. Lahm, R. Gentz, M. Brockhaus, H. Tabuchi, and W. Lesslauer. 1990. Molecular cloning and expression of the $55 \mathrm{Kd}$ tumor necrosis factor receptor. Cell. 61:351-360. 
13. Dinarello, C. A., J. G. Cannon, S. M. Wolff, H. A. Bernheim, B. Beutler, A. Cerami, I. S. Figari, M. A. Palladino, Jr., and J. V. O'Connor. 1986. Tumor necrosis factor (cachectin) is an endogenous pyrogen and induces production of interleukin 1. J. Exp. Med. 163:1433-1450.

14. Perlmutter, D. H., C. A. Dinarello, P. I. Punsal, and H. R. Colten. 1986. Cachectin/tumor necrosis factor regulates hepatic acute-phase gene expression. $J$. Clin. Invest. 78:1349-1354.

15. Torti, F. M., B. Dieckmann, B. Beutler, A. Cerami, and G. M. Ringold. 1985. A macrophage factor inhibits adipocyte gene expression: an in vitro model of cachexia. Science (Wash. DC). 229:867-869.

16. Tracey, K. J., B. Beutler, S. F. Lowry, J. Merryweather, S. Wolpe, I. W. Milsark, R. J. Hariri, T. J. Fahey, A. Zentella, J. D. Albert, G. Shires, and A. Cerami. 1986. Shock and tissue injury induced by recombinant human cachectin. Science (Wash. DC). 234:470-474.

17. Okusawa, S., J. A. Gelfand, T. Ikejima, R. J. Connolly, and C. A. Dinarello. 1988. Interleukin 1 induces a shock-like state in rabbits. Synergism with tumor necrosis factor and the effect of cyclooxygenase inhibition. J. Clin. Invest. 81:1162-1172.

18. Saklatvala, J. 1986. Tumour necrosis factor alpha stimulates resorption and inhibits synthesis of proteoglycan in cartilage. Nature (Lond.). 322:547-549.

19. Bertolini, D. R., G. E. Nedwin, T. S. Bringman, D. D. Smith, and G. R Mundy. 1986. Stimulation of bone resorption and inhibition of bone formation in vitro by human tumor necrosis factor. Nature (Lond.). 319:516-518.

20. Dayer, J.-M., B. Beutler, and A. Cerami. 1985. Cachectin/tumor necrosis factor stimulates collagenase and prostaglandin $E_{2}$ production by human synovial cells and dermal fibroblasts. J. Exp. Med. 162:2163-2168.

21. Collins, T., L. A. Lapierre, W. Fiers, J. L. Strominger, and J. S. Pober. 1986. Recombinant human tumor necrosis factor increases mRNA levels and surface expression of HLA A,B antigens in vascular endothelial cells and dermal fibroblasts in vitro. Proc. Natl. Acad. Sci. USA. 83:446-450.

22. Pober, J. S., L. A. Lapierre, A. H. Stolpen, T. A. Brock, T. A. Springer, W. Fiers, M. P. Bevilacqua, D. L. Mendrick, and M. A. Gimbrone, Jr. 1987. Activation of cultured human endothelial cells by recombinant lymphotoxin: comparison with tumor necrosis factor and interleukin 1 species. J. Immunol. 138:33193324.

23. Defilippi, P., P. Poupart, J. Tavernier, W. Fiers, and J. Content. 1987 Induction and regulation of mRNA encoding 26-kDa protein in human cell lines treated with recombinant human tumor necrosis factor. Proc. Natl. Acad. Sci. USA. 84:4557-4561.

24. Matsushima, K., K. Morishita, T. Yoshimura, S. Lavu, Y. Kobayashi, W. Lew, E. Appella, H. F. Kung, E. J. Leonard, and J. J. Oppenheim. 1988. Molecular cloning of a human monocyte-derived neutrophil chemotactic factor (MDNCF) and the induction of MDNCF mRNA by interleukin 1 and tumor necrosis factor. J. Exp. Med. 167:1883-1893.

25. di Giovine, F. S., G. Nuki, and G. W. Duff. 1988. Tumour necrosis factor in synovial exudates. Ann. Rheum. Dis. 47:768-772.

26. di Giovine, F. S., A. Meager, H. Leung, and G. W. Duff. 1988. Immunoreactive tumour necrosis factor alpha and biological inhibitor(s) in synovial fluids from rheumatic patients. Int. J. Immunopathol. Pharmacol. 1:17-26.

27. di Giovine, F. S., J. A. Symons, and G. W. Duff. 1989. Interleukin 1 and tumour necrosis factor in the pathogenesis of septic arthritis. In Infections and
Arthritis. J. J. Calabro and W. Carson Dick, editors. Kluwer Academic Publishers, Lancaster, UK. 121-133.

28. Duff, G. W., and E. Atkins. 1982. The detection of endotoxin by in vitro production of endogenous pyrogen: comparison with limulus amebocyte lysate gelation. J. Immunol. Methods. 52:323-332.

29. Flick, D. A., and G. E. Gifford. 1984. Comparison of in vitro cell cytotoxic assays for tumor necrosis factor. J. Immunol. Methods. 68:167-175.

30. Marmenout, A., L. Fransen, J. Tavernier, J. Van der Heyden, R. Tizard, E. Kawashima, A. Shaw, M. J. Johnson, D. Semon, R. Muller, et al. 1985. Molecular cloning and expression of human tumor necrosis factor and comparison with mouse tumor necrosis factor. Eur. J. Biochem. 152:512-522.

31. Kaczmarek, L., B. Calabretta, and R. Baserga. 1985. Expression of cell cycle dependent genes in phytohemagglutinin-stimulated human lymphocytes. Proc. Natl. Acad. Sci. USA. 82:5375-5383.

32. Feinberg, A. P., and B. Vogelstein. 1984. A technique for radiolabelling DNA restriction endonuclease fragments to high specific activity. Anal. Biochem. 137:266-274.

33. White, B. A., and F. C. Bancroft. 1982. Cytoplasmic dot hybridization: simple analysis of relative mRNA levels in multiple small cell or tissue samples. $J$. Biol. Chem. 257:8569-8576.

34. Feramisco, J. R., J. E. Smart, K. Burridge, D. M. Helfman, and G. P. Thomas. 1982. Co-existence of vinculin and vinculin-like protein of higher molecular weight in smooth muscle. J. Biol. Chem. 257:11024-11031.

35. Decker, T., M. L. Lohmann-Matthes, and G. E. Gifford. 1987. Cell-associated tumor necrosis factor (TNF) as a killing mechanism of activated cytotoxic macrophages. J. Immunol. 138:957-962.

36. Sariban, E., K. Imamura, R. Luebbers, and D. Kufe. 1988. Transcriptional and posttranscriptional regulation of tumour necrosis factor gene expression in human monocytes. J. Clin. Invest. 81:1506-1510.

37. Beutler, B., N. Krochin, I. W. Milsark, C. Luedke, and A. Cerami. 1986. Control of cachectin (tumor necrosis factor) synthesis: mechanism of endotoxin resistance. Science (Wash. DC). 232:977-980.

38. di Giovine, F. S., J. A. Symons, and G. W. Duff. 1988. Protein/mRNA analysis of monokine production. Lymphokine Res. 7:271-272. (Abstr.)

39. Guerne, P.-A., R. Terkeltaub, B. Zuraw, and M. Lotz. 1989. Inflammatory microcrystals stimulate interleukin- 6 production and secretion by human monocytes and synoviocytes. Arthritis Rheum. 32:1443-1452.

40. Terkeltaub, R., C. Zachariae, D. Santoro, J. Martin, P. Peveri, and K. Matsushima. 1990. IL-8 as a potential mediator of crystal-induced synovitis. Arthritis Rheum. 33:S20. (Abstr.)

41. Elias, J. A., K. Gustilo, W. Baeder, and B. Freundlich. 1987. Synergistic stimulation of fibroblast prostaglandin production by recombinant interleukin 1 and tumor necrosis factor. J. Immunol. 138:3812-3816.

42. Stashenko, P., F. E. Dewhirst, W. J. Peros, R. L. Kent, and J. M. Ago 1987. Synergistic interactions between interleukin 1 , tumor necrosis factor, and lymphotoxin in bone resorption. J. Immunol. 138:1464-1468.

43. Ruggiero, V., and C. Baglioni. 1987. Synergistic anti-proliferative activity of interleukin 1 and tumor necrosis factor. J. Immunol. 138:661-663.

44. Philip, R., and L. B. Epstein. 1986. Tumour necrosis factor as immunomodulator and mediator of monocyte cytotoxicity induced by itself, gamma-interferon and interleukin-1. Nature (Lond.). 323:86-89. 